\title{
The Division of Labour in Czech Households in the 1990s*
}

\author{
ALENA KŘížKKOVÁ ** \\ Institute of Sociology, Academy of Sciences of the Czech Republic, Prague
}

\begin{abstract}
This article aims to outline the basic division of household tasks in Czech families in the 1990s. It deals primarily with the two-income family, which is the norm in the Czech Republic. The starting point is a discussion of the construction of gender roles and their stereotypical reproduction in the family. This leads to the domain of the household and the related responsibilities, which virtually always fall to women. The article makes extensive use of a database from sociological surveys of the family carried out during the 1990s. In the overwhelming majority of households all usual chores are done by women, including caring for children. In comparison with other similar countries of 'Eastern' Europe, however, the division of work in the Czech Republic is one of the most equitable. Nevertheless, such work is still not very highly esteemed here. The article also looks at trends among both men and women towards changing relations with household tasks and at the subjective view of the justice of the division.
\end{abstract}

Czech Sociological Review, 1999, Vol. 7 (No. 2: 205-214)

Housework is an important subject in the question of gender roles in the family. It is influenced both by various factors in the social environment and by the family's internal problems. It is paradoxical that in Czech society today, when the nature of paid work is changing so greatly that physical strength is losing its importance and women are irrevocably part of the labour market, men are still more often preferred for paid work and women are considered more suited to housework, which is overwhelmingly manual. ${ }^{1}$

This article aims to identify the basic empirical nature of housework and its division between men and women in Czech families in the 1990s, as shown in sociological surveys of the family. One point that must be taken into account at the outset is that the two-income household is the norm in this country today. In such families both partners are in full-time paid employment. ${ }^{2}$ Women's careers are virtually only interrupted by maternity leave [Čermáková 1995] and they are complicated by a 'second shift' of housework. As will be seen later, the fact that most housework in this country is done by women is a result of the stereotypical view on the division of gender roles that prevails in society. This stereotype is based on the assumption that women are naturally carers and defenders of the hearth and has been carried over into the set of roles assigned

\footnotetext{
*) This article is supported by grant no. 403/970586 from the Grant Agency of the Czech Republic, "The Position of Women University Graduates in Czech Society in the 1990s".

**) Direct all correspondence to: Alena Kř́žzová, Institute of Sociology, Academy of Sciences of the Czech Republic, Jilská 1, 11000 Praha 1, e-mail krizkova@soc.cas.cz

1) In $1996,59 \%$ of men and $49 \%$ of women agreed with the statement that "The man should earn the money and the woman look after the house" [Rodina '96 1996].

2) In the Czech Republic in 1991 (the last census) these accounted for $62 \%$ of all households [for further details see Podrobné... 1998]. In 1996, 87.8\% of all women of working age were working, the overwhelming majority in full-time jobs, and $7.7 \%$ were on maternity leave. $92.6 \%$ of all men of working age were employed [Zaměstnanost... 1996].
} 
to women in connection with the even stronger stereotype of women's predestination as experts in caring for and raising children. This view assigns men to achievement on the labour market, through which they will basically fulfil all their roles in the family.

\section{The Situation in the Czech Republic}

One factor which is a major determinant of how work in the house is allotted and done women's employment - has not changed as much in this country in the 1990s as may have been expected. The percentage of women employed has stayed the same, ${ }^{3}$ but both the distribution of their jobs (businesswomen represent $7 \%$ of all working women and an increasing number of women $-49 \%$ of all working women - are working in the tertiary sector: banking, insurance, trade [Statistická... 1998]) and their social conditions have changed. For many women paid work has ceased to be an absolute certainty and many women are living with the sense that their jobs are at risk. ${ }^{4}$

Between 1991 and 1995 women living in two-income households reported an increased workload (44\%), less job security (52\%), and fewer job opportunities $(60 \%)$ or opportunities to change their employer (44\%). Their situation is further complicated by the fact that $40 \%$ reported a decline in the level and availability of nursery and pre-school facilities [Pracujicí... 1995].

Czech women have not been able to stay at home during the 1990s, principally because most families need a second income. Here the Czech Republic is still very different from the model prevailing in western countries, where women far more often stay at home or work only part-time. Czech women have to share their strength between two shifts, even though the demands placed on them by their paid employment are continually increasing. At the same time, the family load on women is also changing, undoubtedly due to the increasing demands of their partners' jobs. Unlike their partners, however, women cannot simply cut back on their workload in the family when their outside job becomes more demanding.

In this situation it could be expected that more families would use the now available services providing housework, but only $1 \%$ of households do in fact make use of these [Rodina... 1994]. This is partly due to the low value placed on housework in this country and so to the feeling that it is unnecessary to pay for it. Using such services is often seen as a form of snobbery, but this is also partly due to the negative connotations of such services carried over from the pre-1989 period, when there was an unsuccessful attempt at a state level to transfer housework to services.

Housework should be seen primarily in the context of paid work, as a second shift. Seeing housework as women's work counts with women's lesser involvement on the labour market and so creates the parallel idea of the man's more difficult role as the provider, i.e. $100 \%$ employed. Women's paid work is thus marginalized in the context of housework. The quantitative difference between the time spent by men and women on these two shifts can be seen in Tables 1 and 2. Men living in a two-income family devote an average of 48.5 hours a week to their jobs and women 42.5 hours, while on average

3) Women make up $44.5 \%$ of all people of working age who are employed [Zaměstnanost... 1996].

4) By the normal measures, 5\% of women were unemployed in 1996 (3.7\% of men), ranging from $2.1 \%$ in Prague to $8.1 \%$ in Northern Moravia. For women with only elementary education this figure rises to $10.6 \%$ [Statistická... 1998]. 
men spend 10 and women 25 hours on housework [Rodina '96 1996]. Women therefore work two and a half times as long as men in the home. This asymmetry is not however balanced out by the difference in time spent on paid employment and women's average total working week is 67.5 hours, compared with 58.5 hours for men.

Table 1. Time spent per week on paid employment by economically active married men and women in the Czech Republic, in percentages

\begin{tabular}{lcccccc} 
& $0-10$ & $11-20$ & $21-30$ & $31-40$ & $41-50$ & 50 and more \\
\hline Men & 2.7 & 0.2 & 0.7 & 17.6 & 55.7 & 23.0 \\
Women & 1.5 & 1.5 & 6.6 & 29.5 & 54.5 & 6.3 \\
\hline
\end{tabular}

Source: Rodina '96 survey.

Table 2. Time spent per week on housework by economically active married men and women in the Czech Republic, in percentages

\begin{tabular}{lcccccc} 
& $0-10$ & $11-20$ & $21-30$ & $31-40$ & $41-50$ & 50 and more \\
\hline Men & 72.0 & 20.0 & 5.7 & 1.2 & 1.0 & 0.0 \\
Women & 9.6 & 34.3 & 37.3 & 13.0 & 3.6 & 2.1 \\
\hline Source: & Rodina '96 survey. & & & &
\end{tabular}

\section{Housework}

Narrowing down the discussion to the question of housework, the central fact is its unpaid nature, from which various other factors flow. There is no disagreement over the fact that housework is indeed work, but the problem begins when we begin to look at its productiveness. Is housework a productive activity, when according to economic theories it is not part of the market?

The concept of housework as unpaid because unproductive does not take into account the fact that if this work is done by someone other than a member of the family, it becomes paid work. If outside labour is hired to do this work, is it in some way done better or more professionally? The answer to this must be no, its value only increases because it is paid for. Why is the only obstacle to the unpaid nature of this work the fact that it is outside the market? And indeed is this so? On the labour market, in the Czech Republic as elsewhere, one of the basic assumptions and so reasons for the inferior position of women's work is and always was the assumption that each women works a second shift, in the home, and so cannot devote herself to her paid employment to the same degree as can a man [Vodáková 1992, Čermáková 1997].

Housework is one of the main elements in the social construction of women's identity in society. This assumption justifies its status and unpaid work. The problem lies in the fact that we see this as work like any other work, but at the same time we see it as a part of women's natural existence, particularly in marriage [Delphy 1984, Pateman 1997]. This 'justifies' its unpaid nature, as complementary to a man's role as the provider [Bernard 1987], who is therefore more involved in his paid work.

In the Czech Republic, women's presence on the labour market is taken for granted. Even if society often realises that the load on both sexes from paid employment is increasing, the women still copes with 'her' work at home, because she feels that she 
must. This also contributes to the lower status of such work. Even if men often also do housework today, their participation is often seen as 'helping' their partner with 'her' work. The present ideas (and practice) therefore de facto affect all 'life choices' of women in this country.

The solution to the problem does not lie in how to make this work paid, etc. but rather in the possibility of increasing its status in society. This is because the continuing low status of housework creates conflicts in the role of women who work full-time and also lowers the status of those women who have chosen to devote themselves to their home and looking after their children and see this as their main source of self-realisation, and of women on maternity leave.

Arlie Hochschild considers that "housework would have higher status if men did more of it" [Hochschild 1989: 515]. This assumption is clearly derived from the higher value of men's work than women's work which continues to be present in social stereotypes. In the Czech Republic before 1989 men did in fact often share the work in the house. This was either due to a lack of other opportunities for self-realisation, which they resolved by turning to do-it-yourself, household repairs, etc., or to the fact that the general scarcity of goods on the market forced men to produce items or tools which were freely available in other countries. Unfortunately there is no data from that period to bear out this hypothesis, but it is certain that whether or not it was in fact the case, even this form of male participation in the work of the household did not increase its status. The stereotype of such work still prevailed. ${ }^{5}$ The Czech situation thus de facto overturns Arlie Hochschild's hypothesis.

My task here is to use secondary analysis of data from sociological surveys of the family carried out in recent years to answer certain concrete questions relating to work in the house and to identify any specific features of housework in Czech families in comparison with some other European countries. These questions include who (man or woman) does what, how important this work is for each sex, what aspirations people hold in relation to the amount of work done, and an overall assessment of the concrete division of labour in the household.

\section{Who Does What?}

To analyse the actual situation relating to housework more deeply, it is necessary first to define what activities are included under this term. If it is to include all activities for which different authors use the term, these could be listed as follows, without the list being complete: cooking, washing dishes, cleaning, taking out the rubbish, washing, ironing, shopping, mowing the lawn, gardening, clearing away snow, caring for children or a sick member of the family [Delphy 1984, Oakley 1974, Abbott and Wallace 1990].

In major surveys in the Czech Republic these activities are usually divided into various items and respondents are asked who usually or always does them. The most

\footnotetext{
5) No great importance is placed on housework in the Czech Republic. In 1996 it was rated 3 on a scale from 1 - least important to 5 - most important. Housework was thus placed second to last among such other values such as having the highest possible education and qualifications, having time for one's own interests, having interesting and useful work, living for one's family and children, achieving success and recognition, having plenty of money and living well, a quiet life without risks and tension. In the last place came gardening and household repairs.
} 
common activities are: ironing, shopping, caring for a sick family member, cooking and minor repairs.

Some theorists use a more precise division of those activities more commonly done by women: cooking, washing dishes, cleaning, looking after clothes, caring for children, and those more commonly done by men: household repairs, car repairs, mowing the lawn, clearing away snow, cooking outdoors. They also define a group of activities which are gender-neutral: shopping for food, gardening, accounting for income and expenditure, socialisation of children.

The above list of activities is however insufficient for a detailed analysis in the Czech Republic. From the division of housework in a two-income Czech family shown in Table 3, it can be seen that none of the activities listed can be said to be typically men's work. Washing clothes is almost exclusively done by women in this country (95\%). Other activities (caring for the sick, shopping and cooking) are usually or always done by women in about $60 \%$ to $70 \%$ of cases. Men, however, do not (usually or always) do any of the activities in more than $5 \%$ of cases. The activity which is most often seen as men's work is minor household repairs and it is in fact that which men most often do. According to the male respondents, men do these usually or always in $37.5 \%$ of households (although in a similar or even larger percentage it is the woman). Women set this figure rather lower at only $29.7 \%$.

Of all the activities in question in the Czech Republic those which are 'normally' done are listed below (Table 3). These are the most routine tasks in the home. It can be seen that men in the Czech Republic do not take a systematic part in housework and to find out more about men's (and women's) work in the house, a more detailed list of activities is required.

Table 3: Division of individual activities in the home by sex among economically active people living with a spouse or partner in the Czech Republic, in percentages

\begin{tabular}{lcccc} 
Task & Sex & $\begin{array}{c}\text { Usually or always } \\
\text { the woman }\end{array}$ & Both the same & $\begin{array}{c}\text { Usually or always } \\
\text { the man }\end{array}$ \\
\hline Washing clothes & $\mathrm{M}$ & 93.1 & 5.8 & 1.2 \\
\multirow{2}{*}{ Minor repairs } & $\mathrm{W}$ & 96.7 & 2.1 & 1.3 \\
& $\mathrm{M}$ & 38.6 & 23.9 & 37.5 \\
Caring for the sick & $\mathrm{W}$ & 48.3 & 22.0 & 29.7 \\
& $\mathrm{M}$ & 65.8 & 34.2 & 0.0 \\
Everyday shopping & $\mathrm{W}$ & 69.3 & 30.3 & 0.4 \\
\multirow{3}{*}{ Cooking } & $\mathrm{M}$ & 63.6 & 32.9 & 3.5 \\
& $\mathrm{~W}$ & 71.3 & 23.2 & 5.5 \\
& $\mathrm{M}$ & 60.3 & 36.2 & 3.5 \\
\hline
\end{tabular}

Source: $\quad$ Rodina 1994 survey.

The most recent family survey in this country was in 1996. It looked at the division of care for children (Table 4) but did not analyse housework by different tasks. 
Table 4. $\quad$ Answers to the question: "Who in your family spends most time with the children?" among economically active people living with a spouse or partner in the Czech Republic, in percentages

\begin{tabular}{lccc} 
& Mostly the woman & Both together & Mostly the man \\
\hline Man & 68.2 & 30.3 & 1.5 \\
Woman & 60.8 & 37.7 & 1.6 \\
\hline
\end{tabular}

Source: Rodina' '96 survey.

For all tasks in the household and in caring for children there is a significant difference between men and women, even when the sample includes individual respondents rather than couples. It seems that either women have overestimated their role or men have underestimated that of women. I tend to think that the former is the case, due to women's strong sense of responsibility for this work. The most notable difference is in the answers about minor repairs. In $48.3 \%$ of cases women claimed that they always do this work or usually, while men set their participation at $38.6 \%$. Here I tend to think that men overestimated their participation, largely because this is considered 'men's work', even if it is often done by women.

This assessment of over- or underestimation of participation in housework does not however apply to caring for children (see Table 4), where the situation is the reverse, with men seeing women as more likely to spend time with children than women themselves claimed.

Comparing the Czech Republic with other European countries, the country with the most equitable distribution of housework between partners is the Netherlands (Table 5). There, around $60 \%$ of work in the household is done by both partners. In this respect Europe is split into east and west, with this split being influenced primarily by the type of household investigated. Limiting the sample to dual-income households means that in eastern Europe only a minimal number of respondents were excluded from the representative sample. In western Europe, where women more often stay at home or work only part-time, the dual-income household is, however, a common type and in itself implies a more equitable division of work in the home.

From the subjective point of view, the division of housework in the Czech Republic is closer to that in the Netherlands than in other former Eastern Bloc countries considered. The eastern European country where housework is most often left to the woman is Poland. 
Table 5. Performance of household tasks by sex and country, among people living with a spouse or partner and working full-time, in percentages

\begin{tabular}{lcccc} 
Country & Sex & Usually or Always me & Both & $\begin{array}{c}\text { Usually or always } \\
\text { my partner }\end{array}$ \\
\hline Czech Republic & $\mathrm{M}$ & 0.5 & 33.5 & 65.9 \\
& $\mathrm{~W}$ & 63.3 & 37.0 & 1.7 \\
Hungary & $\mathrm{M}$ & 2.8 & 31.2 & 66.0 \\
\multirow{5}{*}{ Poland } & $\mathrm{W}$ & 65.9 & 30.2 & 3.9 \\
\multirow{3}{*}{ West Germany } & $\mathrm{M}$ & 4.4 & 23.6 & 71.9 \\
\multirow{4}{*}{ Netherlands } & $\mathrm{W}$ & 77.6 & 17.2 & 5.2 \\
& $\mathrm{~W}$ & 1.1 & 46.0 & 52.9 \\
\multirow{2}{*}{ Great Britain } & $\mathrm{M}$ & 59.2 & 30.3 & 10.5 \\
& $\mathrm{~W}$ & 1.0 & 57.6 & 41.4 \\
& $\mathrm{M}$ & 33.8 & 61.8 & 4.4 \\
Source: & $\mathrm{W}$ & 3.6 & 47.0 & 49.4 \\
& 69.6 & 26.6 & 3.8
\end{tabular}

Source: $\quad$ Sociální spravedlnost 1991 survey.

\section{Aspirations}

It has been shown that men in the Czech Republic participate very little in the routine work of the household, and it is interesting to consider whether they have considered increasing their participation. As can be seen from Table 6, in 1996 around 18\% of men wanted to spend more time on work in the house, although around the same percentage of women also wished to do so. No significant relationship was found between the time spent on housework and the wish to spend more.

A relatively large percentage of women, however, would like to spend less time on household tasks. Table 6 provides a fairly good picture of the major changes under way in women's housekeeping role, and also the lesser but still present changes in the corresponding men's role.

Table 6. $\quad$ Answers to the question: "Would you like to spend more, the same or less time on work in the house than you do at present?" among fully employed men and women living with a spouse or partner in the Czech Republic, in percentages

\begin{tabular}{lccccc} 
& Much more & A little more & The same & A little less & Much less \\
\hline Men & 1.5 & 16.3 & 64.5 & 15.5 & 2.2 \\
Women & 2.1 & 18.3 & 46.4 & 28.1 & 5.1 \\
\hline
\end{tabular}

Source: Rodina' 96 survey.

\section{Evaluation}

To date there has only been one attempt to understand how people really feel about housework in this country: the international comparative survey, Social Justice, in 1991 which asked whether people feel the division of household tasks in their family to be just. This assessment (Table 7) can be compared with Table 5, which showed at least the broad outlines of the division of work in this country. 
It was to be expected that men would feel that it was more just than did women, since it is more to the former's advantage, and this was indeed the case. One possible surprise is that of all European countries, men in the Czech Republic had the greatest sense of the injustice of the division of work in the house, and it can be assumed that this was seen as unjust towards women. In all the Eastern European countries considered, women saw this division as more unjust than did women in Western Europe, even though all respondents were from two-income households.

Table 7. The subjective assessment of the justice or injustice of the division of household tasks by sex and country among fully employed people living with a spouse or partner, in percentages

\begin{tabular}{lccc} 
Country & Sex & Just & Unjust \\
\hline Czech Republic & M & 73.1 & 26.9 \\
Hungary & $\mathrm{W}$ & 72.8 & 27.2 \\
& $\mathrm{M}$ & 78.0 & 22.0 \\
Poland & $\mathrm{W}$ & 71.3 & 28.7 \\
& $\mathrm{M}$ & 82.3 & 17.7 \\
West Germany & $\mathrm{W}$ & 63.8 & 36.2 \\
& $\mathrm{M}$ & 90,8 & 9,2 \\
Netherlands & $\mathrm{W}$ & 84.2 & 15.8 \\
\multirow{3}{*}{ Great Britain } & $\mathrm{M}$ & 87.9 & 12.1 \\
& $\mathrm{~W}$ & 85.3 & 14.7 \\
& $\mathrm{M}$ & 79.5 & 20.5 \\
\hline
\end{tabular}

Source: $\quad$ Sociální spravedlnost 1991 survey.

The hypothesis mentioned above that society sees caring for the home as more important for women was basically confirmed even from the responses of individual participants. In 1996 men placed the importance of caring for the home at an average of 2.9 on a scale from $1=$ the least to $5=$ the most important, a figure significantly lower than the average figure of 3.3 for women [Rodina '96 1996].

Women are well aware that housework is still seen as women's work and often accept this. They place greater importance on such work than men do, as can be seen from the fact that women also value their participation in this work rather higher than do men.

\section{Conclusions}

In the Czech Republic housework is virtually always done by women. This work is significantly influenced by women's 'second shift' of work in their paid job. The five most frequent activities (washing, caring for the sick, minor repairs, shopping, cooking) cannot be divided into 'men's' and 'women's' work. Even minor household repairs, stereotyped as men's work, are not clearly the domain of men in this country. Despite the increasing demands of women's paid jobs and so the greater difficulty of combining these two shifts in women's lives, there has been no clear rise in the use of other persons (members of the extended family or paid help) to carry out housework. This option is used by only $1 \%$ of households. 
Even if the division of work in Czech families is one of the most equitable of all the Eastern European countries surveyed, Czech men see this as more unjust than do the men of any other European country. It is clear that conditions in society are forcing both men and women to realise that women's work in the home can no longer be taken for granted, as $18 \%$ of men would like to spend more time on work in the house, and $23 \%$ of women would like to spend less. There is, however, a clear inconsistency here. Czech men may see the division of work in the household as unjust (as far back as 1991), but they still spend only a minimum of time on such activities.

Translated by April Retter

ALENA KŘIZŽKOVÁ graduated from the Faculty of Social Sciences of Charles University in Prague. Since 1996 she has been a researcher in the Institute of Sociology of the Czech Academy of Sciences, as a member of the team studying stratification and the family and since 1998 of the "Gender in Sociology" team, where she is primarily concerned with gender roles in the family and the position of women in partnerships and the household.

\section{References}

Abbott, P., C. Wallace 1990. An Introduction to Sociology: Feminist Perspectives. New York: Routledge.

Bernard, J. 1987. "The Good-Provider Role." Pp. 177-192 in Gender Roles, ed. by E. D. Salamon and B. W. Robinson. Toronto: Methuen.

Čermáková, M. 1995. "Gender, společnost, pracovní trh" [Gender, Society, Labour Market]. Sociologický časopis 31: 7-24.

Čermáková, M. 1997. "Postavení žen na trhu práce" [Women in the Labour Market]. Sociologický časopis 33: 389-404.

Delphy, C. 1984. Close to Home. A materialist analysis of women's oppression. London: Hutchinson.

Hochschild, A. 1989. "The Second Shift: Employed Women are Putting in Another Day of Work at Home." Pp. 515-519 in Men's Lives, ed. by M. S. Kimmel and A. M. Messner. Boston: Allyn \& Bacon.

Oakley, A. 1974. The Sociology of Housework. Bath: The Pitman Press.

Pateman, C. 1997. "Beyond the Sexual Contract?" Pp. 1-19 in Rewriting the Sexual Contract, ed. by G. Dench. London: Institute of Community Studies.

Podrobné výsledky šetření reprodukce a rodiny 1997 [A Detailed Report on the Family and Fertility Survey 1997]. 1998. Praha: ČSÚ.

Pracujicí žena a rodina [Working Women and the Family]. 1995. (Research database). Praha: Sociologický ústav AV ČR and IREX.

Rodina 1994 - sociologický výzkum sociálnich podminek české rodiny [Family 1994 - a sociological survey of the social conditions of the Czech Family]. 1994. (Research database). Praha: Sociologický ústav AV ČR and Universitas.

Rodina '96 [Family '96]. 1996. (Research database). Praha: Sociologický ústav AV ČR, STEM and Hestia.

Sociální spravedlnost [Social Justice] 1991. (Research database). Praha: Sociologický ústav AV ČR and STEM.

Statistická ročenka České republiky 1997 [Statistical Yearbook of the Czech Republic 1997]. 1998. Praha: ČSÚ.

Vodáková, A. 1992. "K 'filosofii' ženské pracovní a životní dvourole" [On the 'Philosophy' of Women's Double Role in Work and Life]. Filosofický časopis 40: 769-781. 
Zaměstnanost v národním hospodářství ČR v roce 1996 [Employment in the National Economy of the Czech Republic in 1996]. Praha: ČSÚ. 